\title{
FLUORESCENCE DEQUENCHING ASSAYS OF CORONAVIRUS FUSION
}

\author{
Victor C. Chu, Lisa J. McElroy, Beverley E. Bauman, \\ and Gary R. Whittaker*
}

\section{INTRODUCTION}

For all enveloped viruses, a critical event during entry into cells is the fusion of the viral envelope with the membrane of the host cell. ${ }^{1,2}$ Our current understanding of viral fusion has been driven by fundamental problems first solved with influenza hemagglutinin (HA). ${ }^{3}$ Whereas the trigger for HA-mediated fusion is the low $\mathrm{pH}$ of the endosome, other viruses (e.g., paramyxoviruses and most retroviruses) undergo a receptor-primed fusion with the plasma membrane at neutral $\mathrm{pH} .{ }^{1}$ In the case of coronaviruses, however, there is little consensus as to whether virus entry and fusion occur following endocytosis or at the plasma membrane. $^{4,5}$

The coronavirus spike protein (S) is a primary determinant of cell tropism and pathogenesis, being responsible (and apparently sufficient) for receptor binding and fusion. ${ }^{6}$ The S protein is categorized as a class I fusion protein, based on the presence of characteristic heptad repeats $^{7-9}$; as such it shows features of the fusion proteins of influenza virus (HA), retroviruses (Env), and paramyxoviruses (F), for which there is extensive characterization at structural and biophysical level. ${ }^{10}$ Although class I fusion proteins share similar structural features, they can have quite different biological properties; i.e., they can be triggered for fusion by low $\mathrm{pH}$ or by receptor interaction. Receptor-induced conformational changes have been described for several coronaviruses, and the virus has generally been considered to exhibit a neutral or slightly alkaline $\mathrm{pH}$ optimum. ${ }^{5}$ However, these fusion data are principally based on cell-cell fusion assays with S-expressing cells and may not recapitulate the fusion event that takes place during virus entry. Indeed, despite being considered to be $\mathrm{pH}$-independent for fusion, there is increasing evidence that coronavirus entry is a low $\mathrm{pH}$-dependent process as infection is sensitive to endosome neutralization. ${ }^{11}$

A powerful means of analyzing membrane fusion is the application of fluorescence assays. These techniques offer a number of advantages, including high sensitivity, relative ease in obtaining quantitative data, and the possibility of monitoring fusion by

*Cornell University, Ithaca, New York 14843. 
either spectrofluorimetry or fluorescence microscopy. ${ }^{12}$ In particular, an assay that has found wide application in studies of virus fusion is that based on relief of fluorescence self-quenching. ${ }^{13,14}$ Fusion of many different viruses has been studied with great effect using this technique; these include influenza virus, Sendai virus, vesicular stomatitis virus, and avian leukosis virus, among others. The assay involves the exogenous insertion of a fluorescent probe, typically octadecyl-rhodamine B chloride (R18), into the viral envelope by briefly incubating a virus suspension with an ethanolic solution $(<1 \% \mathrm{v} / \mathrm{v})$ of the probe. The concentration of the probe is such that it will cause efficient quenching of fluorescence when inserted into the lipid bilayer of the virus, yet when viruses fuse with nonlabeled target membrane the probe becomes diluted and its surface density decreases. A concomitant increase in fluorescence is observed, which increases proportionally with fusion progression, allowing kinetic and quantitative measurements of fusion to be made. ${ }^{15} \mathrm{R} 18$ is by far the most widely used probe used for FdQ studies. Other fluorescent probes with self-quenching properties, e.g., DiO, DiI, etc., may be used for fusion studies, but these have generally not found wide acceptance. Recently however, DiD has been used with notable impact in an analysis of influenza virus fusion by single-particle tracking, ${ }^{16}$ and the use of alternative probes with different fluorescent properties (e.g., resistance to photobleaching, use in double-label experiments, etc.) may become more accepted in the future.

Avian infectious bronchitis virus (IBV) is a coronavirus that can be isolated, purified and labeled appropriately for molecular studies of virus fusion. Here, we examined coronavirus-cell fusion using fluorescence dequenching (FdQ) assays of octadecyl rhodamine (R18)-labeled viruses with host cells. We used a pathogenic strain of IBV (Massachusetts 41), in combination with primary chick kidney (CK) cells.

\section{METHODS}

\subsection{Virus Purification}

IBV (strain Massachusetts 41) was obtained from Dr. Benjamin Lucio-Martinez, Unit of Avian Health, Cornell University and propagated in 11-day-old embryonated chicken eggs. Virus was harvested from the allantoic fluid after $48 \mathrm{~h}$ of infection and purified on a sucrose gradient prior to labeling for FdQ studies.

\subsection{Fluorescence Dequenching (FdQ) Fusion Assay}

Fusion assays were based on fluorescence dequenching of octadecyl rhodamine (R18)-labeled virus. ${ }^{13,17}$ Typically, $100 \mu 1$ of purified virus $(2 \mathrm{mg} / \mathrm{ml})$ was labeled by the addition of $1 \mu \mathrm{l}$ of $1.7 \mathrm{mM}$ octadecyl-rhodamine B chloride (R18) (Molecular Probes) and the mixture was incubated in the dark on a rotary shaker at room temperature for 60 min. Excess dye removed with a Sephadex G25 column (Pharmacia). Under such labeling and purification conditions there was no significant drop in virus infectivity (data not shown). Fifteen microliters of labeled virus (approximately $5 \mathrm{pfu} / \mathrm{cell}$ ) was bound to $1.5 \times 10^{6}$ cells at $4^{\circ} \mathrm{C}$ for $1 \mathrm{~h}$ in binding buffer (RPMI1640 medium containing with $0.2 \%$ $\mathrm{BSA}, \mathrm{pH}$ 6.8). Unbound virus was removed by washing with binding buffer and cells were resuspended in fusion buffer ( 5 mM HEPES, $5 \mathrm{mM}$ MES, $5 \mathrm{mM}$ succinate, $150 \mathrm{mM}$ 
$\mathrm{NaCl}$ (HMSS) buffer, $\mathrm{pH} 7.0,15 \mu \mathrm{M}$ monensin) at $37^{\circ} \mathrm{C}$. Fusion of IBV with the cell membrane was triggered by adding a pre-titrated amount of $250 \mathrm{mM} \mathrm{HCl}$ to obtain a final $\mathrm{pH}$ of between 5.0 and 7.0. FdQ was measured using a QM-6SE spectrofluorimeter (Photon Technology International), with excitation and emission wavelengths set to 560 $\mathrm{nm}$ and $590 \mathrm{~nm}$ respectively. Fusion efficiency was determined following addition of Triton X-100 (final concentration 1\%) to obtain 100\% dequenching.

\subsection{Preparation of Primary Chick Kidney (CK) Cells}

SPF White Leghorn Chicks (11-14 days of age) were placed in a $\mathrm{CO}_{2}$ chamber for an appropriate amount of time such that the chick expires, but not long enough for large amounts of individual cell necrosis (typically $5 \mathrm{~min}$ ). The chick was then placed on a clean surface. After rinsing down with water to dampen feathers (to reduce dust), the skin was opened. Using a new pair of sterile scissors, the abdomen muscle was opened and kidneys removed from each side of the chick. Kidney tissue was placed in $25-50 \mathrm{ml}$ sterile PBS and the container shaken gently to remove clots and red blood cells. The supernatant containing the cells was removed by carefully decanting, and cells rinsed a second time with an equivalent volume of sterile PBS. $25 \mathrm{ml}$ trypsin/EDTA was added and allowed to rinse/digest for approx. 5 min with a stir bar on a stir plate (or by handswirling). The trypsin/EDTA was decanted or aspirated and a further $25 \mathrm{ml}$ more trypsin/EDTA added. This was then allowed to digest for 10-15 min with a stir bar on stir plate (or by hand-swirling). The supernatant was poured through sterile cheesecloth into sterile beaker and the trypsin/EDTA digest repeated 1-2 more times until all chunks of tissue were digested. Ten to $15 \mathrm{ml}$ calf serum was then added to neutralize the trypsin/EDTA and the neutralized supernatant placed into a $50 \mathrm{ml}$ Falcon tubes and centrifuged at 1,000 rpm for $2 \mathrm{~min}$. Cells were resuspended in $25 \mathrm{ml} \mathrm{M} 20$ media and counted on a hemocytometer. Cells were adjusted to a concentration of $1-1.5 \times 10^{6} / \mathrm{ml}$ with M25 media containing 5\% FBS.

\section{RESULTS}

R18-labeled virus was bound to the surface of CK cells at $4{ }^{\circ} \mathrm{C}$ and shifted to $37^{\circ} \mathrm{C}$ in fusion buffer $(\mathrm{pH} 7.0)$ in the presence of monensin to prevent any entry from acidic endosomes. Even after a significant time period at $37^{\circ} \mathrm{C}(400 \mathrm{~s})$, we saw little or no dequenching of virus signal that would indicate virus-cell fusion at neutral $\mathrm{pH}$ (Fig. 1). Upon addition of Triton X-100, extensive dequenching occurred showing that the virus binding had occurred and the virions were labeled appropriately. This indicated that the lack of dequenching was due to a lack of fusion activity at pH 7.0. As IBV appeared to be unable to fuse with cells at neutral $\mathrm{pH}$, we wished to determine if coronavirus fusion was $\mathrm{pH}$ dependent. At $\mathrm{pH} 6.0$ and above dequenching was negligible, however at $\mathrm{pH} 5.75$ limited dequenching was apparent. At $\mathrm{pH} 5.5$ and $\mathrm{pH} 5.25$, high levels of dequenching were observable, which were maximal at $\mathrm{pH} 5.0$. At $\mathrm{pH} 5.0$, the overall extent of fusion typically reached between $40 \%$ and $60 \%$ of that in the presence of Triton X-100, with little or no appreciable lag time after $\mathrm{pH}$ change. Below $\mathrm{pH} 5.0$, the fusion reaction was unstable and calibration was not possible (not shown). 


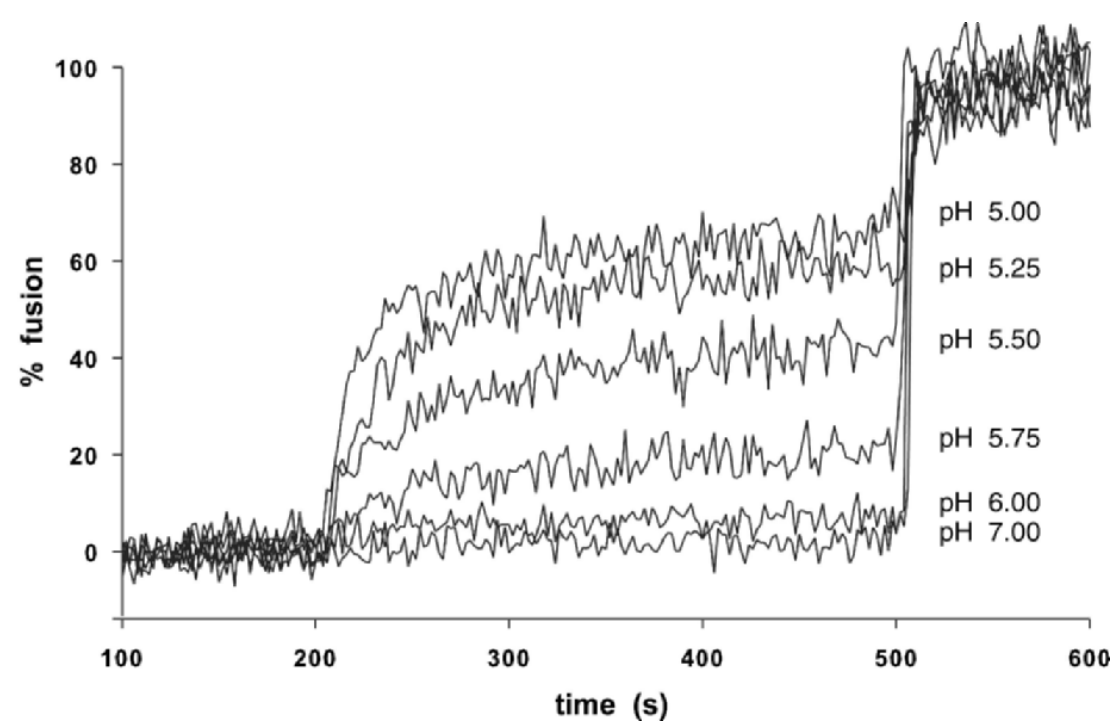

Figure 1. R18-labeled IBV (Massachusetts 41) was bound to $\mathrm{CK}$ cells at $4^{\circ} \mathrm{C}$ and samples added to a spectrofluorimeter cuvette in $\mathrm{pH} 7.0$ buffer maintained at $37^{\circ} \mathrm{C}(\mathrm{t}=0)$. At $\mathrm{t}=200 \mathrm{~s}$, the $\mathrm{pH}$ was reduced to between 6.0 and 5.0, or was maintained at $\mathrm{pH} 7.0$, and samples were monitored for fluorescence dequenching at $37^{\circ} \mathrm{C}$, before addition of $1 \%$ Triton $\mathrm{X}-100$ (final concentration) at $\mathrm{t}=500 \mathrm{~s}$ to obtain complete $(100 \%)$ dequenching.

To define a $\mathrm{pH}$ threshold for fusion, we calculated the initial rate of fusion between pH 7.0 and 5.0 (Fig. 2). Typically, we did not see an abrupt threshold for low-pH activated IBV fusion, as would be expected for influenza virus, ${ }^{18}$ but a more gradual increase in fusion activity between $\mathrm{pH} 6.0$ and 5.0. In our FdQ system, the half maximal $\mathrm{pH}\left(\mathrm{pH}_{1 / 2}\right)$ at which IBV fusion occurred was approximately 5.6.

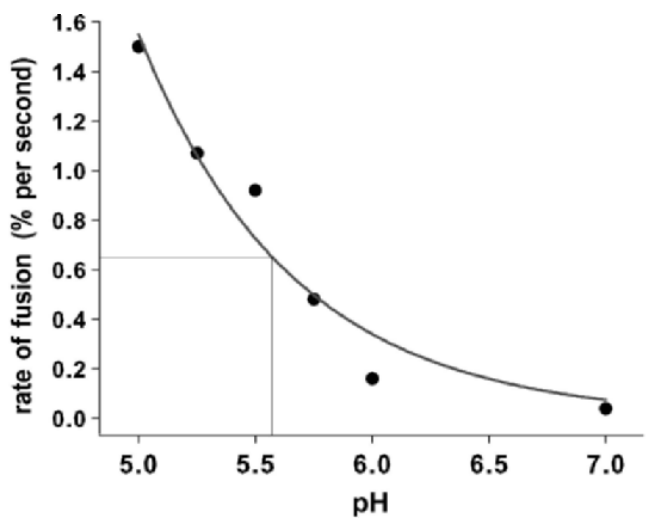

Figure 2. The initial rate of fusion (as obtained from data in Figure 1) was analyzed by 4-parameter, exponential decay and is plotted against $\mathrm{pH}$. The $\mathrm{pH}$ at which the initial rate of IBV fusion was half maximal $\left(\mathrm{pH}_{1 / 2}\right)$ is shown. 


\section{DISCUSSION}

Using an established assay of virus-cell fusion, we show here fusion of the coronavirus IBV with host cells does not occur at neutral $\mathrm{pH}$, and that fusion activation is a low $\mathrm{pH}$-dependent process. How then to rationalize the substantial data showing a neutral $\mathrm{pH}$ coronavirus fusion reaction (at least for cell-cell fusion), with our own data that clearly show activation of virus-cell fusion at $\mathrm{pH} 5.5$ ? We consider one likely explanation is that the coronavirus $\mathrm{S}$ protein has a reversible fusion trigger, as is the case for VSV. ${ }^{19}$ With VSV infection, syncytia can form even with a fusion protein that is clearly triggered by low $\mathrm{pH}^{20}$ In a similar fashion, a fraction of the IBV S protein that is expressed at the cell surface may transiently attain a fusion-competent state during maturation and delivery, allowing cell-cell fusion at the plasma membrane. While the $\mathrm{pH}$ of the Golgi is only mildly acidic, the $\mathrm{pH}$ of secretory vesicles can be as low at $\mathrm{pH} 5.5,{ }^{21}$ and would be low enough to activate fusion in such a model.

Biophysical measurements of viral fusion require relatively large amounts of pure virus preparations. Contamination of the virus preparation with inactive particles or cellular debris complicates the analysis by nonspecific dequenching of the probe. In order to achieve self-quenching, high concentrations of lipid probe need to be incorporated into the membrane, which may produce microcrystals that can also cause nonspecific dequenching. The major disadvantage of FdQ assays, therefore, is the nonspecific redistribution of the probe, which becomes a significant problem when the time of incubation is long. ${ }^{22}$ We have performed extensive analysis of IBV and find no evidence for significant dequenching over the time course of our experiments (not shown).

The early events in coronavirus-cell interactions can be difficult to study, in part because of the tendency of S1 to detach from the virions. ${ }^{23}$ To ensure that we were using intact virus, we analyzed the relative ratio of S1 to S2 of R18-labeled virions by ELISA assays, and saw no significant change after labeling (not shown). Overall, we consider that the fusion monitored by our FdQ studies is a bona fide receptor-mediated event.

One caveat with FdQ studies, such as these presented here, is that fusion is induced at the cell surface by artificially lowering the external $\mathrm{pH}$. Under normal circumstances, fusion would occur following the drop in $\mathrm{pH}$ within the endosome. Although fluorimeterbased studies have been used to monitor viral fusion from endosomes, ${ }^{13}$ it is important to remember that individual fusion events are asynchronous in endosomes and that fluorimeter assays are ensemble experiments; i.e., individual fusion events may be missed with this technique. One future application of fluorescence-based coronavirus fusion assays involves the use of single-particle tracking. ${ }^{16}$ Use of this technique in our laboratory with R18-labeled virus has been hampered due to photobleaching and alternative probes are currently being investigated.

FdQ assays such as those described here are very powerful tools in the study of the fusion event occurring during coronavirus entry, especially when applied in combination with related cell biological and biochemical studies. Ultimately however, a complete understanding of the molecular events in virus fusion awaits the crystallization and structure determination of the intact coronavirus $\mathrm{S}$ protein. 


\section{REFERENCES}

1. L. J. Earp, S. E. Delos, H. E. Park, and J. M. White, The many mechanisms of viral membrane fusion proteins, Curr. Top. Microbiol. Immunol. 285, 25-66 (2004).

2. S. B. Sieczkarski and G. R. Whittaker, Viral entry. Curr. Top. Microbiol. Immunol. 285, 1-23 (2005).

3. J. J. Skehel and D. C. Wiley, Receptor binding and membrane fusion in virus entry: the influenza hemagglutinin. Annu. Rev. Biochem. 69, 531-69 (2000).

4. J. S. Peiris, Y. Guan, and K. Y. Yuen, Severe acute respiratory syndrome, Nat. Med. 10, S88-97 (2004).

5. D. Cavanagh, in: The Coronaviridae, edited by S. G. Siddell (Plenum Press, New York, 1995), pp. 73-113

6. T. M. Gallagher and M. J. Buchmeier, Coronavirus spike proteins in viral entry and pathogenesis, Virology 279, 371-374 (2001).

7. P. Chambers, C. R. Pringle, and A. J. Easton, Heptad repeat sequences are located adjacent to hydrophobic regions in several types of virus fusion glycoproteins, J. Gen. Virol. 71, 3075-3080 (1990).

8. B. J. Bosch, R. van der Zee, C. A. de Haan, and P. J. Rottier, The coronavirus spike protein is a class I virus fusion protein: structural and functional characterization of the fusion core complex, J. Virol. 77, 8801-8811 (2003).

9. Y. Kliger and E. Y. Levanon, Cloaked similarity between HIV-1 and SARS-CoV suggests an anti-SARS strategy, BMC Microbiol. 3, 20 (2003).

10. P. M. Colman and M. C. Lawrence, The structural biology of type I viral membrane fusion, Nat. Rev. Mol. Cell. Biol. 4, 309-319 (2003).

11. H. Hofmann and S. Pohlmann, Cellular entry of the SARS coronavirus, Trends Microbiol. 12, 466-472 (2004).

12. R. Blumenthal, S. A. Gallo, M. Viard, Y. Raviv, and A. Puri, Fluorescent lipid probes in the study of viral membrane fusion, Chem. Phys. Lipids 116, 39-55 (2002).

13. T. Stegmann, H. W. M. Morselt, J. Scholma, and J. Wilschut, Fusion of influenza virus in an intracellular acidic compartment measured by fluorescence dequenching, Biochem. Biophys. Acta 904, 165-170 (1987).

14. D. Hoekstra, T. de Boer, K. Klappe, and J. Wilschut, Fluorescence method for measuring the kinetics of fusion between biological membranes, Biochemistry 23, 5675-5681 (1984).

15. A. Puri, M. J. Clague, C. Schoch, and R. Blumenthal, in: Methods in Enzymology, Vol. 220: Membrane Fusion Techniques Part A, edited by N. Duzgunes (Academic Press, San Diego, 1993), pp. 277-287.

16. M. Lakadamyali, M. J. Rust, H. P. Babcock, and X. Zhuang, Visualizing infection of individual influenza viruses, Proc. Natl. Acad. Sci. USA 100, 9280-9285 (2003).

17. J. M. Gilbert, D. Mason, and J. M. White, Fusion of Rous sarcoma virus with host cells does not require exposure to low pH, J. Virol. 64, 5106-5113 (1990).

18. D. Hoekstra and K. Klappe, in: Methods in Enzymology, Vol. 220: Membrane Fusion Techniques Part A, edited by N. Duzgunes (Academic Press, San Diego, 1993), pp. 261-276.

19. Y. Gaudin, Reversibility in fusion protein conformational changes. The intriguing case of rhabdovirusinduced membrane fusion, Subcell. Biochem. 34, 379-408 (2000).

20. P. C. Roberts, T. Kipperman, and R. W. Compans, Vesicular stomatitis virus $\mathrm{G}$ protein acquires $\mathrm{pH}$ independent fusion activity during transport in a polarized endometrial cell line, J. Virol. 73, 10447-10457 (1999).

21. M. M. Wu, M. Grabe, S. Adams, R. Y. Tsien, H. P. Moore, and T. E. Machen. Mechanisms of pH regulation in the regulated secretory pathway, J. Biol. Chem. 276, 33027-33035 (2001).

22. S. Ohki, T. D. Flanagan, and D. Hoekstra, Probe transfer with and without membrane fusion in a fluorescence fusion assay, Biochemistry 37, 7496-7503 (1998).

23. K. V. Holmes and S. R. Compton, in: The Coronaviridae, edited by S. G. Siddell (Plenum Press, New York, 1995), pp. 55-71. 